\title{
Characterization and recombinant expression of a divergent ice nucleation protein from 'Pseudomonas borealis'
}

Correspondence

Virginia K. Walker

walkervk@queensu.ca

Received 20 October 2008

Revised 23 December 2008

Accepted 1 January 2009

\author{
Zhongqin Wu, ${ }^{1}$ Lei Qin $^{1}$ and Virginia K. Walker ${ }^{1,2}$ \\ ${ }^{1}$ Department of Biology, Kingston, ON K7L 3N6, Canada \\ ${ }^{2}$ Department of Microbiology and Immunology, Kingston, ON K7L 3N6, Canada
}

\begin{abstract}
Isolates of 'Pseudomonas borealis' were recovered after ice-affinity selection of summercollected soils. 'P. borealis' DL7 was further characterized and shown to have ice nucleation activity (INA), a property that allows the crystallization of ice at temperatures close to the melting point, effectively preventing the supercooling of water. INA was optimally detected after culturing at temperatures consistent with psychrophilic growth. The sequence encoding the ' $P$. borealis' ice nucleation protein (INP) was obtained using both PCR and chromosome walking. When expressed in Escherichia coli, the resulting inaPb recombinants had INA. The 'P. borealis' sequence, dubbed inaPb, is clearly related to previously cloned INP genes, but it shows greater divergence. Sequence analysis suggests that there are two opposite flat surfaces, one relatively hydrophobic that likely serves as an ice template, and the other that could function as a complementary face to facilitate interprotein interaction for ice-step formation.
\end{abstract}

\section{INTRODUCTION}

It is only the presence of ice nucleators that ensures the crystallization of water at temperatures close to $0{ }^{\circ} \mathrm{C}$; without them water would supercool. Apart from ice itself, the most active known ice nucleators are found in bacteria. Several decades ago the plant epiphyte Pseudomonas syringae was discovered to have ice nucleation activity (INA) (Maki et al., 1974). It was speculated that INA contributed to its pathogenicity since freezing and subsequent wounding of the leaves and stems would allow these strains ready access to plant nutrients (Lindow et al., 1978). More recently, INA has been reported in Pseudomonas fluorescens and Erwinia herbicola, showing similar serological properties to $P$. syringae (Deininger et al., 1988). Isolation of ice nucleation protein (INP) sequences from these, as well as from Xanthomonas campestris, has shown that they are similar despite the evolutionary divergence of the host bacteria (Abe et al., 1989; Warren \& Corotto, 1989). It has been speculated that the sequence was horizontally transferred by transduction events between plant epiphytes (Edwards et al. 1994). These INPs have a conserved amino terminus and a highly repeated middle region of 960-1296 amino acids consisting of three 16-residue repeats (yielding a 48 amino acid unit). This internally periodic middle region accounts for $80 \%$ of

Abbreviations: INA, ice nucleation activity; INP, ice nucleation protein.

The GenBank/EMBL/DDBJ accession number for the sequence of the ' $P$. borealis' INP gene and protein is EU573998. the protein (Warren \& Corotto, 1989) and is followed by a 41-68-residue carboxyl-terminal sequence.

INA is not necessarily correlated with high freeze-thaw resistance. Indeed, in experiments to select for microbes with this phenotype from soil samples, no microbes with previously known INPs were recovered (Walker et al., 2006). However, when bacteria from several temperate soils were adsorbed to growing multicrystalline ice, several isolates, including two 'Pseudomonas borealis' strains (DL7 and YIC), identified on the basis of their 16S rRNA sequences, were recovered in the melt water (Wilson et al., 2006). They were subsequently shown to have INA. Since INA had not been previously observed in these bacteria, the phenotype was examined further to determine if this activity could explain ice association and the gene sequence was isolated to compare it to better known species with this activity.

\section{METHODS}

Bacterial strains. ' $P$. borealis' DL7 originated from soil samples collected from the Tundra Ecosystem Research Station at Daring Lake in the North West Territories, Canada $\left(64^{\circ} 52^{\prime} \mathrm{N}, 111^{\circ} 35^{\prime} \mathrm{W}\right)$. This isolate was recovered after ice-affinity selection as previously described (Wilson et al., 2006). Chryseobacterium sp. C14 was originally isolated by freeze-thaw selection (Walker et al., 2006) and has no INA. Other strains used were $P$. syringae B728a, Escherichia coli TG2 and E. coli BL21 (Novagen).

Characterization of ' $\boldsymbol{P}$. borealis' DL7. A single colony of ' $P$. borealis' DL7 was inoculated in $10 \%$ tryptic soy broth (TSB), cultured 
at $22{ }^{\circ} \mathrm{C}$ for $24 \mathrm{~h}$, stained with Gram dyes according to standard protocols, and examined microscopically at $1000 \times$. The antibioticresistant phenotype was determined on $10 \%$ TSB plates supplemented with different antibiotics and agents, and verified by liquid cultures. The different agents and their concentrations were: ampicillin $\left(100 \mathrm{mg} \mathrm{ml}^{-1}\right)$, kanamycin $\left(50 \mathrm{mg} \mathrm{ml}^{-1}\right)$, tetracycline $\left(15 \mathrm{mg} \mathrm{ml}^{-1}\right)$, streptomycin $\left(100 \mathrm{mg} \mathrm{ml}^{-1}\right)$, and $\mathrm{CuSO}_{4}(0.8 \mathrm{mM})$.

The optimal growth temperature of the isolate was investigated by inoculating a single colony into $10 \%$ TSB, shaking, and monitoring growth at $22{ }^{\circ} \mathrm{C}$. Once the cultures reached stationary phase, new cultures were initiated by inoculating $1 \%$ of the stationary phase cells into fresh $10 \%$ TSB and maintaining the culture temperature at $4{ }^{\circ} \mathrm{C}$, $8{ }^{\circ} \mathrm{C}, 22^{\circ} \mathrm{C}$ or $37^{\circ} \mathrm{C}$. Growth was monitored by both $\mathrm{OD}_{600}$ and viable cell counts (c.f.u. $\mathrm{ml}^{-1}$ ).

Ice nucleation assays and ice affinity. Ice nucleation was assessed using different sample volumes. A thermal analyser was used to determine the freezing point, as assessed by the heat of fusion of firstorder freezing (Borchardt \& Daniels, 1957). A thermister was placed in $1.4 \mathrm{ml}$ samples that were chilled from $5{ }^{\circ} \mathrm{C}$ to $-15{ }^{\circ} \mathrm{C}$ at $0.2{ }^{\circ} \mathrm{C} \mathrm{min}{ }^{-1}$; temperatures were automatically recorded on a spread sheet and subsequently plotted (Walker et al., 2008). Smaller volume samples were assayed essentially as previously described (Vali, 1971; Maki et al., 1974; Kozloff et al., 1983; Wilson et al., 2006). Freezing was monitored visually by a fibreoptic light source directed through crossed polarized filters as the temperature was lowered from $-1{ }^{\circ} \mathrm{C}$ to $-15{ }^{\circ} \mathrm{C}\left(\right.$ at $0.2{ }^{\circ} \mathrm{C} \mathrm{min}^{-1}$ ) and expressed as the logarithm of the number of ice nuclei per cell (Nemecek-Marshall et al., 1993).

Ice affinity was determined as previously described (Wilson et al., 2006). Briefly, the temperature of a hollow brass finger was set at $-1{ }^{\circ} \mathrm{C}$ to establish a thin ice coat, and then it was lowered into a beaker containing the bacteria of interest $\left(1.0 \times 10^{4}\right.$ c.f.u. $\left.\mathrm{ml}^{-1}\right)$. By keeping the ice finger at $-1{ }^{\circ} \mathrm{C}$, an ice hemisphere could be slowly formed. After 2 days, $\sim 50 \%$ of the liquid fraction was frozen, during which time the temperature of the ice finger was lowered incrementally. Subsequently, the hemisphere was rinsed and the ice was melted and poured onto $10 \%$ TSB plates. Identification of the bacteria as well as the numbers of viable cells (c.f.u. $\mathrm{ml}^{-1}$ ) was then determined by using plates without additives or containing the appropriate discriminating antibiotics (tetracycline at $15 \mathrm{mg} \mathrm{ml}^{-1}$, ampicillin at $100 \mathrm{mg} \mathrm{ml}^{-1}$ and streptomycin at $100 \mathrm{mg} \mathrm{ml}^{-1}$ ).

INP sequence determination. Amino acid sequences from known INPs were aligned and degenerate primers were designed to amplify the conserved, repetitive repeats. After initial trials, two primers, INPup (5'-AACATGGCCGATCAYTGCGG-3') and INPdown ( $5^{\prime}$ GTAVCKYTTSCCGTCCCAG-3'), were used. DNA from ' $P$. borealis' DL7 was isolated using standard phenol/chloroform methods in PCR experiments under the following conditions: $94{ }^{\circ} \mathrm{C}$ for $5 \mathrm{~min}$, followed by $94{ }^{\circ} \mathrm{C}$ for $0.5 \mathrm{~min}, 55{ }^{\circ} \mathrm{C}$ for $0.5 \mathrm{~min}, 72{ }^{\circ} \mathrm{C}$ for $4 \mathrm{~min}$ for 35 cycles, finishing with an extension at $72{ }^{\circ} \mathrm{C}$ for $30 \mathrm{~min}$. The products were separated on agarose gels, purified using standard methods (Nucleotide removal kit, Qiagen), and the recovered PCR products were ligated into pGEMT vector (Promega). A plasmid with the appropriately sized insert was sequenced by ACGT Corporation and named pGEMcoreinp.

Based on the known sequence, four more primers were used to extend the 5 '-terminal sequence of the putative ' $P$. borealis' INP gene. The template for first reverse PCR was ' $P$. borealis' genomic DNA, which was cut by SalI and self-ligated overnight, then purified as previously indicated. The PCR product $(1 \mu \mathrm{l})$ of the first two primers (INPR887: 5'-ATAGAATTCTGCCGTAGCCCGCAGTGAGAT-3' and INPL1549: $5^{\prime}$-CCTCGGGTTATGGCAGTTCCC-3') was used as template for a second PCR with two new primers (INPR188: 5'-TCAGCCTGCATATTCAAATGCG-3' and INPL2573: 5'-ACCCAGACTGCCCAGG-
AAGA-3'). A similar method was used for $3^{\prime}$-terminal extensions. The product $(1 \mu \mathrm{l}$ ) from the first PCR amplification (using primers INPL3396: 5'-ATAGAATTCCGGGCGACCGAAGCAAACTATTG-3' and INPR3350: 5'-CGGCCATCTGGATGCTGTCGGC-3') were used in a second amplification (with INPL3581: 5' -CTGACGGGCGGCGA GAACTCG-3' and INPR2768: 5'-TGCGTACTTCCATAACCTGCGACCAGT-3'). Both PCR products were ligated into pGEMT and positive colonies were designated pGEM5extension and pGEM3extension, respectively.

After sequencing, alignments were made using BioEdit for pGEMcoreinp, pGEM5extension and pGEM3extension. Similarities between the putative ' $P$. borealis' INP sequence and all 13 known INPs in the database were determined by BLAST (Altschul et al., 1997) and a consensus sequence was produced using the statistical tool hidden Markov models (HMM) according to Schuster-Böckler et al. (2004). Alignments with multiple sequences were made with the coding regions of INP genes from the following microbes: 'P.borealis', $P$. fluorescens (inaW), P. syringae B728a, P. syringae (inaV), Pantoea ananatis (inaA), Pantoea agglomerans, X. campestris (inaX) and Xanthomonas translucens. Separate alignments were assembled for the repetitive region, as well as the amino- and carboxyl-terminal regions using BioEdit. The maximum-likelihood model was employed using ProML (Felsenstein, 2004), which does not assume a molecular clock, and this was used for the phylogenetic trees.

Expression of recombinant 'P. borealis' INP. PCR was performed to introduce a NotI site to pGEM3extension with primers EC32 (5' GCGAATTCTCATTATTCCCCGGATTTATTCACG-3') and EL2351 (5'-GGATCCATGGCAGGCTTCCAAAGCACATTGAT-3'), and the product was ligated to pGEMT and named pGEM2351. Subsequently, pGEM2351 was cut with SalI and ligated to pGEMcoreinp that had been digested by the same enzyme, and the recovered plasmid was designated pGEM3core. Another PCR was performed to introduce an EcoRI site at the $5^{\prime}$-terminal site of pGEM5extension using primers EN11 (5'-GGGAATTCGGGATGAACGATGACAAAG-3') and EN22 (5'-CGTAGATCTATCGCCAGCGGTTTCGGTA-3'). The resulting amplified product was ligated to pGEMT and designated pGEM1122, which was then digested using XhoI and ligated to pGEM3core, which had been digested with same restriction enzyme. The sequence of pGEMeinp was then obtained. Finally, the putative INP gene was introduced to pET24a at the EcoRI and NotI sites by digesting both the vector and pGEMeinp. This last plasmid was designated pET24aINP.

A single colony of E. coli BL21(DE3) harbouring pET24aINP was used to inoculate $10 \mathrm{ml}$ Luria-Bertani (LB) broth containing $30 \mu \mathrm{g}$ kanamycin $\mathrm{ml}^{-1}$. After culture at $37{ }^{\circ} \mathrm{C}$, IPTG was added to $1 \mathrm{mM}$ when the $\mathrm{OD}_{600}$ reached 0.6 . Subsequently the culture was shifted to $4{ }^{\circ} \mathrm{C}$ for $3 \mathrm{~h}$. INA was assessed in the transformed cells as well as control cultures treated like the transformed cells and as previously stated.

\section{RESULTS}

\section{Growth and characterization of 'P. borealis' DL7}

' $P$. borealis' DL7, which had been previously isolated by ice affinity (Wilson et al., 2006), was microscopically visualized as Gram-negative cells, $\sim 0.5 \times 3 \mu \mathrm{m}$ (not shown). Cultures grew well on $10 \%$ TSB, with a maximum cell density at $10^{9}$ c.f.u. $\mathrm{ml}^{-1}$, corresponding to an $\mathrm{OD}_{600}$ of 1.1. Colonies on $10 \%$ TSB plates were white with round and smooth margins. ' $P$. borealis' DL7 can be broadly classified as psychrophilic since there was growth at $22{ }^{\circ} \mathrm{C}$ 
(doubling time of $3.3 \mathrm{~h}$ ), but cultures also grew well at $8{ }^{\circ} \mathrm{C}$ and $4{ }^{\circ} \mathrm{C}$ (with a doubling time of $12.6 \mathrm{~h}$ and $13.6 \mathrm{~h}$, respectively). Even after 1 year of storage at temperatures at $0{ }^{\circ} \mathrm{C}$, with ice floating on the surface of the medium, the cultures remained viable with no diminution of INA (see below).

When characterized in the presence of selected additives (see Methods), ' $P$. borealis' DL7 continued to divide in the presence of ampicillin, but growth was inhibited by kanamycin, tetracycline and streptomycin, as well as by $\mathrm{CuSO}_{4}$, amongst others (not shown). Thus the resistance phenotype was distinct from that of E. coli TG2 cells, which were inhibited by ampicillin but not by tetracycline.

\section{INA and ice affinity}

INA in ' $P$. borealis' DL7 was shown using several different methods. As demonstrated in other studies (Vali 1995), absolute ice nucleation temperatures depend not only on cell number, but also on sample size. Thermal profiles of 'P. borealis' ( $\sim 10^{9}$ c.f.u. $\mathrm{ml}^{-1} ; 1.4 \mathrm{ml}$ volume $)$ cultured at $22{ }^{\circ} \mathrm{C}$ and held at $4{ }^{\circ} \mathrm{C}$ for 2 days showed a mean freeze temperature of $-2.8{ }^{\circ} \mathrm{C}$, compared to a mean freeze temperature of $-2.4{ }^{\circ} \mathrm{C}$ for $P$. syringae cultures under the same conditions (Fig. 1 inset). Thermal profiles for the two Pseudomonas species were significantly different from those for E. coli TG2 and Chryseobacterium C14, with mean freeze temperatures of $-6.8{ }^{\circ} \mathrm{C}$ and $-7.1{ }^{\circ} \mathrm{C}(P<0.03)$. Ice nucleation spectra showed the same trend, although at temperatures consistent with the smaller volumes used to assess large numbers of samples, and confirmed that ' $P$. borealis' had levels of INA (expressed as the logarithm of the number of ice nuclei per cell) that were slightly lower than that of P. syringae (Fig. 2).

Although INA appeared to be independent of growth phase (not shown), it was affected by culture temperature. There was little INA (log ice nuclei per cell between -6 and -7 ) in ' $P$. borealis' cultures at $22{ }^{\circ} \mathrm{C}$, but substantially more activity (log ice nuclei per cell between -2 and -4 ) at $4{ }^{\circ} \mathrm{C}$ or $8{ }^{\circ} \mathrm{C}$. Likewise, when cells cultured at $22{ }^{\circ} \mathrm{C}$ reached stationary phase and were transferred to $4{ }^{\circ} \mathrm{C}$ for 2 or 4 days, a substantial increase in INA was observed (log ice nuclei per cell increased from about -7 to -4 and -2 , respectively). There was no INA and no growth at $37{ }^{\circ} \mathrm{C}$.

' $P$. borealis' DL7 was originally isolated after incorporation into growing ice and therefore its relative ice affinity was compared to that of E. coli. Identification of the two bacteria was facilitated by their sensitivity to different antibiotics. Although it was not possible to accurately estimate ' $P$. borealis' cell numbers in the unfrozen liquid fraction because it is a psychrophile, there was an average fivefold higher recovery of ' $P$. borealis' in the ice fraction compared to E. coli TG2 (not shown). This higher recovery could only be partially attributed to the threefold higher survival of ' $P$. borealis' compared to $E$. coli in the ice fraction $(P<0.001)$.

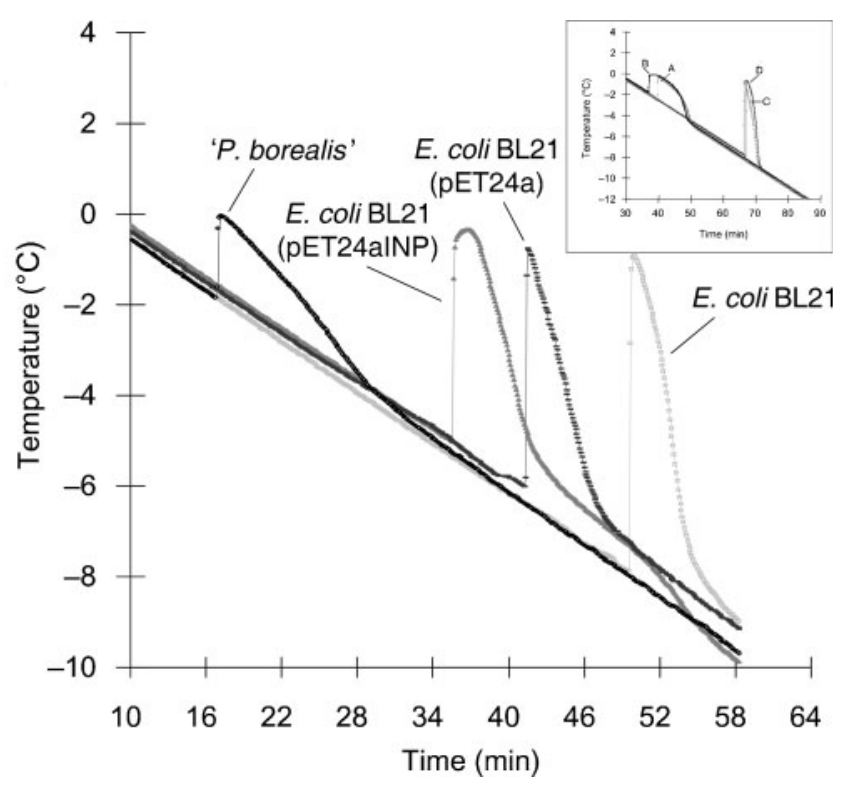

Fig. 1. INA of ' $P$. borealis' DL7. Typical thermal profiles showing the release of the heat of crystallization for ' $P$. borealis' ( $\diamond$; $\left.-1.9{ }^{\circ} \mathrm{C}\right)$ and $E$. coli BL21 $\left(\square ;-7.9{ }^{\circ} \mathrm{C}\right)$; transformed E. coli BL21 contained either pET24a $\left(-;-6.0{ }^{\circ} \mathrm{C}\right)$ or PET24alNP $\left(\boldsymbol{\Delta} ;-5{ }^{\circ} \mathrm{C}\right)$ containing the ' $P$. borealis' inaPb coding region. The inset shows further control experiments with ' $P$. borealis' DL7 $\left(A ;-2.5^{\circ} \mathrm{C}\right)$ compared to $P$. syringae $\mathrm{B} 728 \mathrm{a}$ strain $\left(\mathrm{B} ;-1.8{ }^{\circ} \mathrm{C}\right)$ cultures as well as control samples of $E$. coli TG2 $\left(\mathrm{C} ;-7.9^{\circ} \mathrm{C}\right)$ and Chryseobacterium sp. $\mathrm{C} 14\left(\mathrm{D} ;-7.7^{\circ} \mathrm{C}\right)$. Typical thermal profiles are shown; experiments were done three to five times using independent cultures.

\section{Isolation, sequence and analysis of the ' $P$. borealis' INP gene}

Previously reported INP gene sequences (Wolber et al., 1986) allowed the design of 'consensus' DNA primers for the amplification of a DNA fragment from ' $P$. borealis'. Eventually, degenerate primers (see Methods) were used to successfully amplify a $3.6 \mathrm{~kb}$ product (not shown). After cloning in pGEMT, subsequent sequencing allowed the synthesis of 'exact match' primers, which were used in a reverse PCR strategy to extend the sequence in both directions.

After assembly of the sequenced fragments, the resulting putative ' $P$. borealis' INP DNA sequence conceptually encoded 1244 residues. The amino-terminal region extended for about 163 residues and accounted for $13 \%$ of the gene, with the carboxyl-terminal region making up 41 residues. The remainder $(\sim 84 \%)$ of the sequence was highly repetitive, with 65 typical 16 amino acid repeats (GenBank accession EU573998). The pattern was generally of two relatively hydrophilic repeats followed by a more hydrophobic 16-residue repeat for each 48 amino acid repeat unit. Comparison of the ' $P$. borealis' DNA sequence indicated that there was no homologue amongst previously 


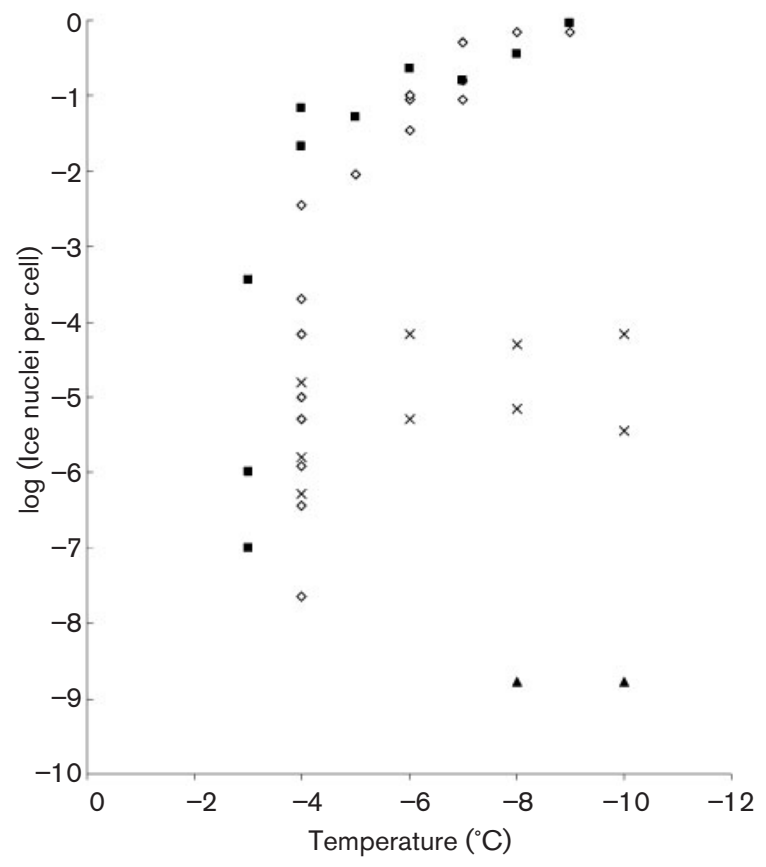

Fig. 2. INA expressed as the logarithm of the cumulative number of ice nuclei per microbial cell $(10 \mu \mathrm{l}$ samples) for decreasing temperatures. Samples tested included ' $P$. borealis' DL7 $(\diamond), P$.

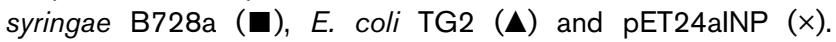
Cultures were grown at $22{ }^{\circ} \mathrm{C}$ and transferred to $4{ }^{\circ} \mathrm{C}$ for 24 days. Typical data are shown with the experiments done in triplicate.

known INP genes in the first $500 \mathrm{bp}$. Overall there was $\sim 66 \%$ identity with P. syringae INP. Phylogenetic analysis (Fig. 3a) showed that ' $P$. borealis' INP was divergent from the better-known INPs but overall had more similarity to the $P$. fluorescens protein. Not unexpectedly, the repeat sequences showed the highest identity with other INPs. ' $P$. borealis' INP (e.g. position 164-1076) had a consensus sequence of AGYGSTxTAgxxSxLi/t (Fig. 3b), compared to the consensus AGYGSTQTsGseSsLT repeat in $P$. syringae InaZ (Kajava \& Lindow, 1993).

\section{Recombinant ' $P$. borealis' INP is functional}

To confirm that the PCR-amplified sequence encoded the INP, separate DNA fragments were amplified using primers containing judiciously chosen restriction sites. Subsequently, digestion with the appropriate restriction enzymes allowed the fragments to be assembled by ligation such that the entire 3735 bp sequence was introduced into pET24a. After inducing the E. coli host and transferring to $4{ }^{\circ} \mathrm{C}$, the expressed recombinant INP showed modest but consistent INA: $1.4 \mathrm{ml}$ samples froze at a mean of $-5{ }^{\circ} \mathrm{C}$ (Fig. 1) compared to a mean of $-7{ }^{\circ} \mathrm{C}$ for control cells (non-transformed or E. coli-transformed with an 'empty' pET24a plasmid). Ice nucleation spectra confirmed that transformed E. coli had modest levels of INA (log ice nuclei (a)

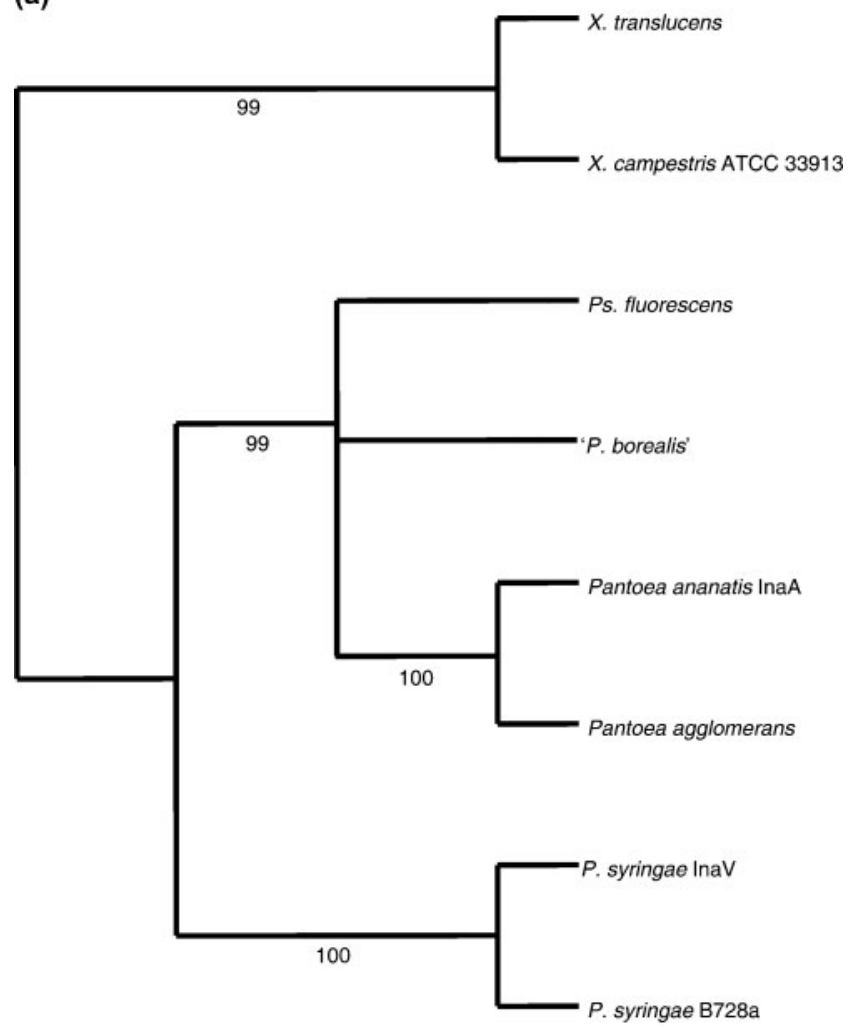

(b)

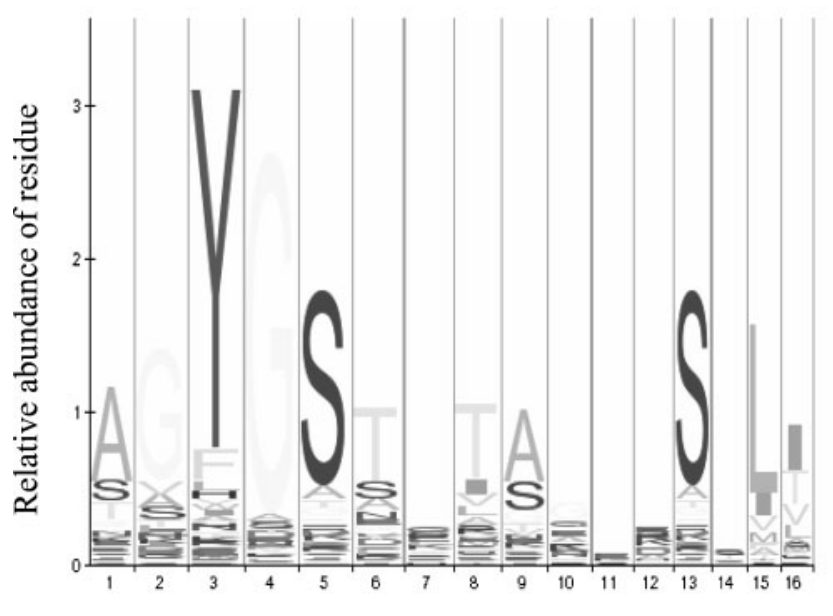

Residue position in consensus

Fig. 3. The INP in ' $P$. borealis' DL7. (a) Phylogenetic tree of the INP from ' $P$. borealis' with other representative INPs (BioEdit). (b) The 16 amino acid repeat (positions 164-1076) in ' $P$. borealis' is depicted showing the frequency of each amino acid as indicated by the relative size of the letters. The 16-residue unit is repeated three times to make a 48-residue unit, which itself is repeated 19 times (along with eight more 16 amino acid repeats).

per cell between -4.2 and -6.3 ), which surpassed that of the controls (Fig. 2). Based on these functional assays, the gene sequence has been designated inaPb. 


\section{DISCUSSION}

Survival in a surface tundra community demands adaptations to long cold winters. Reports list more than a dozen microbes that appear to dominate low-temperature consortia and these include Pseudomonas species (WynnWilliams, 1983; Shivaji et al., 1989). Some Pseudomonas strains are known to degrade hydrocarbon spills, particularly in the Arctic (Stallwood et al., 2005), valuable 'cold enzymes' have been isolated from others (Villeret et al., 1997; Cavicchioli, 2002), and membranes of some strains have enhanced fluidity at low temperatures (Kumar et al., 2002). Strains of $P$. syringae are well known for their INPs, and this phenotype might also be considered a lowtemperature adaptation. ' $P$. borealis' DL7 originated from tundra soils and was recovered by ice-affinity selection, an isolation that we now show appears to have been partially due to its ability to retain high viability after freezing, as well as its modest ice affinity. Indeed, because this strain is easily cultivated at temperatures just a few degrees above $0{ }^{\circ} \mathrm{C}$ and did not divide at $37^{\circ} \mathrm{C}$, it can be classified as a psychrophile. ' $P$. borealis' DL7 showed typical pseudomonad properties, including its cell and colony morphology, but in addition it had INA. This activity is apparent above $-5{ }^{\circ} \mathrm{C}$ (Figs 1 and 2), allowing the ' $P$. borealis' INP to be classified as a high-activity, type I nucleator (Phelps et al., 1986).

INA has been described in certain strains of several evolutionarily diverse plant pathogens and epiphytic bacteria, and the genes encoding the INPs are homologous (Abe et al., 1989; Warren \& Corotto, 1989; Edwards et al., 1994). Since ' $P$. borealis' is considered a beneficial soil bacterium (Raaijmakers et al., 2002), it was of interest to determine the sequence of its INP. Cloning the corresponding gene was challenging due to the large number of internal repeats (GenBank accession EU573998; Fig. 3), with alternative cloning strategies yielding disappointing results, but eventually the sequence was isolated using PCR and chromosome-walking techniques. To ensure that the INP had been correctly identified, the entire gene was assembled from amplified fragments and used to transform E. coli. The resulting recombinant protein showed modest, but consistent INA (Figs 1 and 2). Similarly, when INP genes from other bacteria are expressed in E. coli, the resulting INA is not as high as in the originator cells (Wolber et al., 1986).

Although we can only speculate that INP might confer some freeze protection to ' $P$. borealis', the identification of the sequence in this soil bacterium and its divergence has prompted us to consider its structure and function. The ' $P$. borealis' INP is composed of a repetitive core and is flanked by non-repetitive hydrophobic amino- and hydrophilic carboxyl-terminal regions, similar to other INPs. The INP genes from Pantoea ananatis, Pseudomonas syringae, Pseudomonas fluorescens and X. campestris are highly conserved, with the main difference being the number of 16-residue repeats. The hydrophobic amino-terminal portion of the ' $P$. borealis' shows no significant identity to other sequences in the database and the carboxyl terminal region was also divergent, with more polar and fewer hydrophilic residues than other INPs, but with similar numbers of charged residues to the $P$. fluorescens protein. When the $\mathrm{InaPb}$ sequence with its overall average $66 \%$ amino acid identity to other INPs was compared in phylogenetic trees, again it was more divergent than sequences from the plant epiphytes, but appeared more closely related to $P$. fluorescens, another soil microbe (Fig. 3). It is not known if inaPb is a result of horizontal gene transfer from an as-yet-unknown donor or if the sequence differences in ' $P$. borealis' and $P$. fluorescens reflect an adaptation to a soil habitat.

Because of the divergence, inaPb should be useful for the discovery of functional residues in INPs. Previously, $P$. syringae INP has been modelled as a $\beta$-fold structure, with 16 residues per turn forming an ice-like surface (Wolber \& Warren, 1989; Kajava \& Lindow, 1993; Graether \& Jia, 2001). Experimental evidence for this model has been provided by structural characterization of a six-turn, truncated polypeptide (Kobashigawa et al., 2005). It is notable that the ' $P$. borealis' sequence can also be modelled with similar folds and similarly has a reiterated TxT (Fig. 3), a motif that has been identified as the flat, ice-adsorption face in the $\beta$-helix antifreeze proteins (AFPs) from moths and beetles (Tyshenko et al., 1997; Graham et al., 1997). A second flat surface on the opposite side of the InaPb $\beta$-fold is predicted to derive from $\mathrm{xLi} / \mathrm{t}$ motifs, where $\mathrm{x}$ is frequently Ser and the Leu residues project inward. Although a model for a grass AFP shows two flat, putative ice-adsorption faces on opposite sides of the $\beta$-roll (Kuiper et al., 2001), we do not believe that this additional motif would have primarily evolved as a second ice-binding surface in INPs. Rather, we speculate that this second face functions to provide a complementary surface for the 'interdigitation' of the INPs (Kajava \& Lindow, 1993). Since INPs are displayed on the membrane surface, two flat surfaces on either side of the $\beta$-folds would allow close inter-protein association along the faces, thus permitting INPs to assemble as three-dimensional 'stairs' consisting of overlapping INP molecules. Since less energy is required for the addition of water molecules to steps (Pruppacher \& Klett, 1997), the propagation of ice along these discontinuities would be greatly facilitated, resulting in proteins that are second only to ice itself in the heterogeneous nucleation of water.

\section{ACKNOWLEDGEMENTS}

We thank Dr G. Palmer for assistance with the thermal analyser and Ms. S. Wilson for the ' $P$. borealis' strain. Drs D. Gutterman and G. Voordouw are acknowledged for the P. syringae B728a and E. coli TG2 strains. Drs Z. Jia, P. Davies and S. Lougheed, and Mr C. Garnham, as well as an anonymous reviewer are thanked for their encouragement. Financial support from a Queen's University Research Chair and NSERC (Canada) is gratefully acknowledged. 


\section{REFERENCES}

Abe, K., Watabe, S., Emori, Y., Watanabe, M. \& Arai, S. (1989). An ice nucleation active gene of Erwinia ananas. Sequence similarity to those of Pseudomonas species and regions required for ice nucleation activity. FEBS Lett 258, 297-300.

Altschul, S. F., Madden, T. L., Schaffer, A. A., Zhang, J., Zhang, Z., Miller, W. \& Lipman, D. J. (1997). Gapped BLAST and PSI-BLAST: a new generation of protein database search programs. Nucleic Acids Res 25, 3389-3402.

Borchardt, H. J. \& Daniels, F. (1957). The application of differential thermal analysis to the study of reaction kinetics. J Am Chem Soc 79, 41-46.

Cavicchioli, R. (2002). Extremophiles and the search for extraterrestrial life. Astrobiology 2, 281-292.

Deininger, C. A., Mueller, G. M. \& Wolber, P. K. (1988). Immunological characterization of ice nucleation proteins from Pseudomonas syringae, Pseudomonas fluorescens and Erwinia herbicola. J Bacteriol 170, 669-675.

Edwards, A. R., Van den Bussche, R. A., Wichman, H. A. \& Orser, C. S. (1994). Unusual pattern of bacterial ice nucleation gene evolution. Mol Biol Evol 11, 911-920.

Felsenstein, J. (2004). PHYLIP (phylogeny inference package) version 3.6. Department of Genome Sciences, University of Washington, Seattle.

Graether, S. P. \& Jia, Z. (2001). Modeling Pseudomonas syringae icenucleation protein as a beta-helical protein. Biophys $J$ 80, 1169-1173.

Graham, L. A., Liou, Y. C., Walker, V. K. \& Davies, P. L. (1997). Hyperactive antifreeze protein from beetles. Nature 388, 727-728.

Kajava, A. V. \& Lindow, S. E. (1993). A model of three-dimensional structure of ice nucleation proteins. J Mol Biol 232, 709-717.

Kobashigawa, Y., Nishimiya, Y., Miura, K., Ohgiya, S. \& Tsuda, S. (2005). A part of ice nucleation protein exhibits the ice-binding ability. FEBS Lett 579, 1493-1497.

Kozloff, L. M., Schofield, M. A. \& Lute, M. (1983). Ice nucleating activity of Pseudomonas syringae and Erwinia herbicola. J Bacteriol 153, 222-231.

Kuiper, M. J., Davies, P. L. \& Walker, V. K. (2001). A theoretical model of a plant antifreeze protein from Lolium perenne. Biophys J 81, 3560 3565.

Kumar, G. S., Jagannadham, M. V. \& Ray, M. K. (2002). Lowtemperature-induced changes in composition and fluidity of lipopolysaccharides in the antarctic psychrotrophic bacterium Pseudomonas syringae. J Bacteriol 184, 6746-6749.

Lindow, S. E., Arny, D. C. \& Upper, C. D. (1978). Distribution of ice nucleation-active bacteria on plants in nature. Appl Environ Microbiol 36, 831-838.

Maki, L. R., Galyan, E. L., Chang-Chien, M. M. \& Caldwell, D. R. (1974). Ice nucleation induced by Pseudomonas syringae. Appl Microbiol 28, 456-459.

Nemecek-Marshall, M., Laduca, R. \& Fall, R. (1993). High-level expression of ice nuclei in a Pseudomonas syringae strain is induced by nutrient limitation and low temperature. J Bacteriol 175, 4062 4070 .
Phelps, P., Giddings, T. H., Prochoda, M. \& Fall, R. (1986). Release of cell-free ice nuclei by Erwinia herbicola. J Bacteriol 167, 496-502.

Pruppacher, H. R. \& Klett, J. D. (1997). Microphysics of Clouds and Precipitation, 2nd edn. New York: Springer.

Raaijmakers, J. M., Vlami, M. \& de Souza, J. T. (2002). Antibiotic production by bacterial biocontrol agents. Antonie Van Leeuwenhoek 81, 537-547.

Schuster-Böckler, B., Schultz, J. \& Rahmann, S. (2004). HMM logos for visualization of protein families. BMC Bioinformatics 5, 7 .

Shivaji, S., Rao, N. S., Saisree, L., Sheth, V., Reddy, G. S. \& Bhargava, P. M. (1989). Isolation and identification of Pseudomonas spp. from Schirmacher Oasis, Antarctica. Appl Environ Microbiol 55, 767-770.

Stallwood, B., Shears, J., Williams, P. A. \& Hughes, K. A. (2005). Low temperature bioremediation of oil-contaminated soil using biostimulation and bioaugmentation with a Pseudomonas sp. from maritime Antarctica. J Appl Microbiol 99, 794-802.

Tyshenko, M. G., Doucet, D., Davies, P. L. \& Walker, V. K. (1997). The antifreeze potential of the spruce budworm thermal hysteresis protein. Nat Biotechnol 15, 887-890.

Vali, G. (1971). Quantitative evaluation of experimental results on the heterogenerous freezing nucleation of supercooled liquid. J Atmos Sci 28, 402-409.

Vali, G. (1995). Principles of Ice Nucleation: Biological Ice Nucleation and its Applications. London: APS Press.

Villeret, V., Chessa, J. P., Gerday, C. \& Van Beeumen, J. (1997). Preliminary crystal structure determination of the alkaline protease from the Antarctic psychrophile Pseudomonas aeruginosa. Protein Sci 6, 2462-2464.

Walker, V. K., Palmer, G. R. \& Voordouw, G. (2006). Freeze-thaw tolerance and clues to the winter survival of a soil community. Appl Environ Microbiol 72, 1784-1792.

Walker, V. K., Wilson, S. L., Wu, Z., Miao, D. N., Zeng, H., Ripmeester, J. A. \& Palmer, G. R. (2008). Screening microbes for ice-associating proteins with potential application as 'green inhibitors' for gas hydrates. In Emerging Environmental Technologies, pp. 29-41. Edited by V. Shah. New York: Springer.

Warren, G. \& Corotto, L. (1989). The consensus sequence of ice nucleation proteins from Erwinia herbicola, Pseudomonas fluorescens and Pseudomonas syringae. Gene 85, 239-242.

Wilson, S. L., Kelley, D. L. \& Walker, V. K. (2006). Ice-active characteristics of soil bacteria selected by ice-affinity. Environ Microbiol 8, 1816-1824.

Wolber, P. \& Warren, G. (1989). Bacterial ice-nucleation proteins. Trends Biochem Sci 14, 179-182.

Wolber, P. K., Deininger, C. A., Southworth, M. W., Vandekerckhove, J., van Montagu, M. \& Warren, G. J. (1986). Identification and purification of a bacterial ice-nucleation protein. Proc Natl Acad Sci U S A 83, 72567260.

Wynn-Williams, D. D. (1983). Distribution and characteristics of Chromobacterium in the maritime and sub-antarctic. Polar Biol 2, 101-108.

Edited by: J. A. Vorholt 